\title{
Assessment of MSMEs Working Capital Loans at Bank Mandiri Malang Branch, Indonesia
}

\author{
Anggraeni Purwatiningsih, Adi Suprayitno, Agus Haryono \\ University of Merdeka Malang, Indonesia
}

\begin{abstract}
This research is motivated by the increasing number of MSMEs. In line with the increasing number of MSMEs, there are constraints in the working capital of MSMEs. Bank Mandiri became one of the state-owned banks that have working capital credit facilities for MSMEs. Low-interest rates compared to other state-owned banks are the main attraction of Bank Mandiri to MSMEs in applying for loans. Bank Mandiri uses the 5 C principle (Character, Capacity, Capital, Collateral, and Condition of Economy) in conducting credit rating of working capital for MSMEs. This research has focus of research in this research is to know how Bank Mandiri Malang Branch performs an assessment of working capital credit for MSMES. The research was carriedout using descriptive qualitative techniques. Techniques of collecting data using interviews, observation, and documentation. In data analysis techniques use data reduction, data presentation, and conclusion. Furthermore, to test the validity of data used source triangulation techniques, method triangulation, and triangulation time. The results showed that (1) Credit assessment using $5 \mathrm{C}$ principle, namely Character, Capacity, Capital, Collateral, and Condition of Economy. Application of 5C principle in credit rating at Bank Mandiri Malang Branch both in accordance with SC elements. (2) There are some optimal 5C elements used by Bank Mandiri, namely Character, Capacity, and Collateral. Advice for Bank Mandiri Malang Branch especially Bank Mandiri Wahid Hasyim, that is needed to be given understanding about SC so that understanding of credit assessment aligned, there should be a monthly monitoring system to ensure working capital credit given to debtor used for its allotment, and give a special program to support effort debtors both in terms of marketing and managerial so that the smoothness will be more secure.
\end{abstract}

Keywords: Assessment, MSMEs, SMEs, Working Capital Loan.

\section{INTRODUCTION}

MSMEs play an important role as one of the drivers of economic development in Indonesia. The role of SMEs is very important for the economy in Indonesia, because almost the entire population of national businesses are businesses categorized as SMEs (Ubaya FE and Forda UKM East Java, 2007:26-27). According to the Law of the Republic of Indonesia Number 20 of 2008 concerning Micro, Small, and Medium Enterprises which states that, "Micro, Small and Medium Enterprises aim to grow and develop their businesses in the context of building a national economy based on equitable economic democracy". With the existence of MSMEs, it will absorb labor so that it can reduce the unemployment rate.

Every year the number of MSMEs in Indonesia increases and increases in number from all business fields. But behind the increase in MSMEs, there are many obstacles, one of which is the problem of capital. This is also stated by Katili et al. (2014) that "Many entrepreneurs fail at the beginning of their business because of capital factors". The definition of working capital according to Suhardjono (2003: 287) is as follows: Working capital is a number of funds used to finance company operations ranging from complaints of raw materials / auxiliary materials to semi-finished materials, to finance labor and overhead costs, the production process of goods to raw materials. is sold or in other words a number of funds / cash embedded in current assets that are used to carry out company activities.

The government strongly supports the existence of MSMEs and hopes that MSMEs in Indonesia will continue to increase and experience development. One of the efforts to increase, develop, and handle MSMEs constraints is credit facility. In an effort to develop MSMEs through the provision of credit, it is necessary to have the role of other parties who can provide credit facilities. One of the parties that can provide credit facilities is the Bank.

Banks are companies engaged in finance, meaning that banking activities are always related to finance (Kasmir, 2012:24). Banks have activities, namely collecting funds, distributing funds and providing other services. Providing other services is a credit facility. Giving credit can provide income for the bank itself and can make a profit. If the income from the loan is greater than the interest costs paid by the bank to customers and other bank operational costs, it can be said that the bank has a healthy condition. 
The bank must carefully assess the debtor in the credit application so that when the bank provides credit the debtor will pay the loan principal and interest on time according to the agreement that has been made and agreed upon.

In July 1999, four state-owned banks namely Bank Bumi Daya, Bank Dagang Negarn, Bank Export Import Indonesia and Bank Pembangunan Indonesia were merged into Bank Mandiri, each of which has an integral role in the development of the Indonesian economy (www.bankmandiri.co.id:13November 2016). In the role of developing the Indonesian economy, Bank Mandiri provides credit facilities for MSMEs.

Bank Mandiri provides People's Business Loans for MSMEs who need Investment Credit (KI) and Working Capital Credit (KMK). People's Business Credit is credit for financing productive business segments of micro, small, medium, and cooperatives that are feasible but not yet bankable for working capital and/or investment credit through direct or indirect (linkage) financing patterns guaranteed by the Credit Guarantee Institution. (www.bankmandiri.co.id:17November 2017). In addition to the People's Business Credit (KUR) Bank Mandiri also provides Micro Business Loans (KUM). Bank Mandiri has several advantages in Working Capital Loans in People's Business Loans compared to other State-Owned Banks, one of which is that the loan interest is only $0.4 \%$ while BRI (Bank Rakyat Indonesia) is $1 \%$. Another advantage of KMK in KUR is the loan limit of IDR 100,000,000, 00 while other banks are only IDR 25,000,000.00. This advantage was conveyed by Dimas Arif Praba Kusuma as MKS (Micro Credit Sales) at Bank Mandiri Merdeka.

The bank as a credit provider before providing bank credit should evaluate prospective debtors both in terms of quality and quantity as consideration in order to avoid various risks. Evaluating in terms of quality, the bank must really know information about prospective debtors, both personal profiles of debtors, business profiles, and debtor history, both history of relationships with other banks that have provided credit facilities to debtors and history of relationships with other companies. While evaluating from a quantitative perspective, it can be seen from the debtor's financial statements which are then analyzed by the bank.

The above is supported in the research of Katili et al. (2014). Saraswati's research (2012) also supports the results of financial statement analysis research that can be used as the basis for approval of lending and an assessment of the 5C principles of prospective debtors before giving credit approval is very important. Arthesa and Handiman (2016:170) explain the definition of credit analysis, that: Credit analysis is the process of processing basic information that has been obtained into complete information. Complete information consists of several factors including opportunities and threats that will affect the business and smooth credit payments. Credit analysis is also complemented by an evaluation of the capital requirements needed by customers.

Providing credit that is less or exceeds the need will be the burden of the debtor itself. If the amount proposed by the debtor exceeds his needs, it will increase the interest expense for the debtor. Likewise, if the amount proposed by the debtor is less than what is needed, the debtor's plan or goal will not work.

\section{LITERATURE REVIEW}

\subsection{Credit}

According to Kasmir (2012:81), "According to its origin, the word credit comes from the word credere which means trust, meaning that if someone gets credit, it means they gain trust. Meanwhile, for the creditor it means giving someone confidence that money what is lent must be returned. According to Firdaus and Ariyanti (2011:1), "Credit implies the existence of a trust from a person or entity that is given to a person or other entity, namely that the person concerned in the future mass will fulfill all obligations that have been agreed in advance". From the explanation of the definition of credit above, it can be concluded that credit is a value containing an agreement or agreement between the creditor and the credit recipient, called the debtor. Credit contains several elements in it, namely creditors, debtors, trust, agreements, risks, time periods, and remuneration.

Basically credit is a risk asset for banks, therefore it is necessary to understand the various risks of lending so as not to become an obstacle in the credit process. The implementation of credit requires supervision that ensures credit utilization, credit repayment and fulfillment of other obligations to the bank. In credit activities there are various kinds of credit risk. Credit risk according to Muljono (2001:80-84), "Business risk, geographical risk, political risk, ucertainty risk, inflation risk, and competition risk". This is supported by Firdaus and Ariyanti (2011: 35-36) who suggest various types of credit risk, "Business risk, geographical risk, risk of security crowds / brawls, political risk / government policies, risk of uncertainty (uncertainty), inflation risk., and competitive risk.

\subsection{Credit Analysis}

Given that credit is a risk asset for banks, it is necessary to carry out a credit analysis before giving credit. Credit analysis is an analytical process carried out by the Bank to assess a credit application that has been submitted by a prospective debtor (Ismail, 2011:111). While credit analysis according to Darmawi (2012: 104): The main purpose of credit analysis is to determine the 
ability and sincerity of a borrower to repay the loan in accordance with the terms in the credit agreement. In a broader sense, credit analysis is the process of assessing the risk of providing loans to companies or individuals.

In credit assessment/analysis there are aspects that need to be assessed, namely:

Arthesa and Handiman (2016:169) state that "In general, every bank applies the 5C principle, namely various assessments of the condition of customers and their business with various risk aspects or better known as risk identification that may arise, accompanied by a complete explanation". The SC principle is useful for banks to know the various risks that may arise and assist in making credit application decisions. Assessment of the 5C principles, among others;

\section{a. Character (Character)}

Characteris an assessment of prospective debtors covering personality, environment, way of life, and history. This assessment will also describe the level of honesty, responsibility and commitment in fulfilling obligations. If the prospective debtor has good responsibility, honesty, and commitment, the creditor will believe that the prospective debtor can repay the credit well. Isamail (2011:112) "Banks want to know that prospective debtors have good character, are honest, and have a commitment to repaying loans that will be received from the bank".

\section{b. Capacity (Abilities)}

Capacityis an assessment carried out by creditors in assessing the ability of prospective debtors to run their business. This assessment aims to determine the ability of prospective debtors in running their business. According to Arthesa and Handiman (2016:171) the information that must be obtained includes:

1) Assessment of business management.

2) Assessment of supply quality (supply).

3) Assessment of production quality.

4) Assessment of marketing quality.

\section{c. Capital (Capital)}

Capitalis the wealth/capital owned by the prospective debtor in its business activities. An assessment can be made based on information regarding the source and structure of capital, the quality of capital management, the effectiveness of the use of capital placement, the quality of profit creation, and the quality of profit utilization (Artthesa and Handiman, 2016:172). This assessment aims to determine the ability of the prospective debtor's business to bear the financing.

\section{d. Condition of Economy (Economic Condition)}

Condition of Economyis a macroeconomic condition that can affect the business activities of prospective debtors. This assessment aims to determine the prospects of prospective debtors in the future and the ability of prospective debtors to maintain their business from macro conditions that can affect their business.

\section{e. Collateral (Guarantee)}

Collateralis a movable object or immovable object of the prospective debtor which is submitted to the creditor as credit guarantee. The purpose of this assessment is to determine the value of the object submitted as credit guarantee. The credit given cannot exceed the value of the object used as collateral. According to Ismail (2011:113) in detail the consideration of collateral is known as MAST:

\section{1) Marketability}

Collateral received by the bank must be collateral that is easily traded at an attractive price and increases from time to time, so that if there is a problem with the repayment of the credit, the bank will easily sell the collateral.

\section{2) Ascertainability of Value}

Collateral received has a more definite price standard, because the collateral is an easily available item, so there is no need to ask for help from an appraisal agency in estimating the price of the collateral item.

\section{3) Subsibility of Value}

Collateral submitted by the bank has a stable price, so that when the collateral is sold, the proceeds from the sale can override the debtor's obligations. 


\section{4) Transferability}

Collateral submitted by the bank is easy to move physically and legally. It is easy for everyone to be able to buy collateral, no need to do complicated permits.

\subsection{Micro, Small and Medium Enterprises (MSMEs)}

Law of the Republic of Indonesia Number 20 of 2008 concerning Micro, Small and Medium Enterprises, article 1 describes the meaning of Micro, Small and Medium Enterprises, namely:

a. Micro Business is a productive business owned by individuals and/or individual business entities that meet the criteria. Micro Enterprises as regulated in this Law.

b. Small Business is a productive economic business that stands alone, which is carried out by individuals or business entities that are not subsidiaries or not branches of companies that are owned, controlled, or become part either directly or indirectly of Medium Enterprises or Large Businesses that meet the Business criteria. Small as referred to in this Law.

c. Medium Enterprises are productive economic businesses that stand alone, which are carried out by individuals or business entities that are not subsidiaries or branches of companies that are owned, controlled, or become part either directly or indirectly with Small Businesses or Large Businesses with total net assets or annual sales proceeds as regulated in this Law.

\section{RESEARCH METHODS}

\subsection{Approach and Type of Research}

This study uses a qualitative approach with a descriptive type of research according to the problem that is the focus of this research. The definition of qualitative methods according to Sugiyono (2018: 9) is as follows: Qualitative methods are research methods based on the philosophy of positivism, used to examine the condition of natural objects, (as opposed to experiments) where the researcher is the key instrument, data collection techniques conducted by triangulation (combined), data analysis is inductive qualitative and qualitative research results emphasize meaning rather than generalization.

\subsection{Data Source}

The sample of data sources at the initial stage of entering the field is to choose people who have power and authority in the social situation or subject under study. This is intended to be able to open the door or entrance to where the researcher will collect data. The primary data source here is used to obtain accurate data because this resource is direct information obtained by researchers through observations and interviews at Bank Mandiri Malang on the Micro Business Cluster and Wahid Hasyim Micro Business Unit as well as debtors who get Working Capital Credit on People's Business Credit in Bank Mandiri Malang. Primary data sources according to Sugiyono (2018:225) are sources that provide data directly to researchers without going through intermediaries, so that the authenticity of the data can be trusted. Primary data sources were obtained from interviews with credit managers, micro credit analysts, micro credit sales and debtors or MSMEs who received working capital loans from Bank Mandiri Malang Branch, as well as field notes from researchers during interviews at Bank Mandiri Malang branch needed for business purposes. researcher. For primary data sources, more details will be presented in the following table.

Table 1. Research Informants

\begin{tabular}{|c|l|ll|}
\hline No & \multicolumn{1}{|c|}{$\begin{array}{c}\text { Primary Data Sources } \\
\text { (Informants) }\end{array}$} & \multicolumn{1}{c|}{ Required Information } \\
\hline 1 & MSMES Credit Manager & a. $\quad$ MSMEs who apply at Bank Mandiri. \\
& & b. $\quad$ Credit terms and policies in general for MSMEs. \\
& & c. $\quad$ Credit terms for MSMEs. \\
\hline 2 & Micro Credit Analyst & e. $\quad$ Credit constraints and solutions \\
\hline 3 & Micro Credit Sales & a. & The process of assessing prospective debtors. \\
\hline
\end{tabular}


International Journal of Research in Social Science and Humanities (IJRSS), Vol. 3 (1), Jan -2022

\begin{tabular}{|c|l|ll|}
\hline No & \multicolumn{1}{|c|}{$\begin{array}{c}\text { Primary Data Sources } \\
\text { (Informants) }\end{array}$} & Required Information \\
\hline & & b. & Data verification process \\
& & c. & Prospective debtor assessment process \\
\hline 4 & Debtor (MSME) & a. & Credit application considerations \\
& & b. $\quad$ Data prepared for credit application \\
\hline
\end{tabular}

Source: Data processed by researchers.

\subsection{Data Analysis}

This research includes descriptive research, so that after the data is collected, the next thing to do is analyze qualitative data. According to Bogdan and Biklen (in Moleong, 2012: 248) qualitative data analysis is an effort made in the way of working with data, organizing data, sorting it into manageable units, synthesizing it, looking for, and finding patterns, finding what is important and what is important. other. The data that has been collected from various data sources will then be analyzed which is divided into 3 parts according to Sugiyono (2018: 246) which include:

\section{1) Data reduction}

Reducing means summarizing, choosing the main and important things and then looking for themes and patterns (Sugiyono, 2018: 247). The data reduction stage according to Moleong (2012:88):

a. Identification of units (units). At first, it was identified the existence of a unit, namely the smallest part found in the data that has meaning when associated with the tax authorities and research problems.

b. After the units are obtained, the next step is to make coding. Making coding means assigning a code to each unit, so that the unit data can be traced, from which source.

The results of interviews and documentation that have been collected will then be filtered so that the data that has been collected can be more focused and data that does not support this research will not be used.

\section{2) Data Presentation}

In this case, Miles and Huberman (Dalum Sugiyono, 2018: 248) state that "the most frequency of display data for qualitative research data in the past has been narrative text" which is most often used to present data in qualitative research is text that is descriptive in nature. narrative.

\section{3) Conclusion Drawing/Verification}

The third step in qualitative data analysis is drawing conclusions and verification. After all the data is presented, the problem that becomes the object of the research can be understood and then a conclusion is drawn which is the result of this research, the conclusion is drawn in the statement sentence of this research. This conclusion drawing is made in a short, dense, and meaningful statement sentence, where the researcher interprets the data that has been reduced so that conclusions can be drawn.

\subsection{Research Stages}

These stages of research are needed by researchers so that research can run smoothly. The research phase in general consists of the pre-field stage, the field work stage, the data analysis stage, and the report preparation stage (Moleong, 2012:127). Based on the description above, the stages carried out by researchers include:

1) Pre-Field Stage, includes

a. Develop Research Design

In this study, the research design has been described in chapters I and II.

b. Choosing a research field 
In this step, the researcher explores and assesses the state of the field regarding the object being observed, so that the research location is obtained, namely Bank Mandiri Malang in the Micro Business Cluster and Wahid Hasyim Micro Business Unit.

c. Select and use information

In this step, the researcher uses the main informants, namely the Credit Manager, Micro Credit Analyst and Micro Credit Sales at Wahid Hasyim's Micro Business Unit, and MSMEs as debtors who have received working capital loans from Bank Mandiri Malang. There are two debtors studied, namely recipients of working capital loans on Micro Business Loans (KUM) and debtors who have become top up customers of working capital loans on People's Business Credit (KUR). So that the five main speakers are expected to be able to assist researchers in providing important information, namely regarding the assessment of MSMES working capital loans at Bank Mandiri Malang branch.

d. Preparing Research Equipment

The equipment prepared is not only physical, but mental preparation needs to be trained beforehand (Moleong, 2012: 133). For this reason, before conducting research, researchers prepare mentally and psychologically. In addition, the researcher also prepared a list of interview questions, recorder and camera for documentation.

e. Research Ethical Issues

In this case, the researcher has a good relationship with one of the employees of Bank Mandiri Malang. However, it is still necessary to be honest with the researcher about what the researcher has obtained in the form of events, stories, so that there is no element of adding, composing, or even replacing the existing information.

2) Field Work Stage

a. Understanding the background of the researcher and self-preparation

In this case, researchers must understand the background of the research, prepare themselves in placing themselves as researchers who are known, have good looks $18 \mathrm{Be}$ polite and courteous when entering field work, and pay attention to the amount of time spent in research, so as not to interfere with the work of the informants.

b. Entering the Field

When entering the field, researchers must establish a close relationship so that research subjects will answer questions voluntarily. In addition, in this study, researchers are required to study the language used by the people in the research setting.

c. Interviews and Collecting Necessary Data

Researchers conducted recorded interviews with the informant's permission and collected some of the necessary data.

3) Data analysis

The data that has been collected by the researcher, will then be analyzed using 3 stages, namely data reduction, data presentation, and drawing conclusions.

4) Preparation of reports

The preparation of the report by the researcher uses a descriptive method that describes the actual situation with a scientific background.

\section{DISCUSSION}

\subsection{Assessment of MSMEs Working Capital Credit at Bank Mandiri Malang}

Based on the research findings, it can be seen that in credit assessment Bank Mandiri uses a 5C assessment. This shows that the $5 \mathrm{C}$ assessment is very important to assess the feasibility of the debtor. The credit assessment includes debtor character assessment, debtor capacity assessment, collateral debtor assessment, debtor capital assessment, and condition of economy assessment. Further discussion regarding the assessment of MSMEs working capital credit at Bank Mandiri is as follows: credit implies the existence of a trust from a person or entity that is given to another person or entity, namely that the person concerned in the future will fulfill all obligations that have been agreed upon in advance. formerly Firdaus and Ariyanti (2011:1). In distributing working capital loans to MSMEs, Bank Mandiri itself is divided into two types, namely Micro Business Credit (KUM) and People's Business Credit (KUR). Micro business credit is credit given to micro entrepreneurs to finance productive 
business needs, both for investment needs and working capital needs. People's Business Credit is credit or financing provided by banks to MSMEs that are feasible but not yet bankable. KUR aims to improve and expand bank services to productive MSMEs to increase the competitiveness capacity of MSMEs. Encouraging economic growth and employment and reducing poverty. Micro business credit is credit given to micro entrepreneurs to finance productive business needs, both for investment needs and working capital needs. People's Business Credit is credit or financing provided by banks to MSMEs that are feasible but not yet bankable. KUR aims to improve and expand bank services to productive MSMEs to increase the competitiveness capacity of MSMEs. Encouraging economic growth and employment and reducing poverty. Micro business credit is credit given to micro entrepreneurs to finance productive business needs, both for investment needs and working capital needs. People's Business Credit is credit or financing provided by banks to MSMEs that are feasible but not yet bankable. KUR aims to improve and expand bank services to productive MSMEs to increase the competitiveness capacity of MSMEs. Encouraging economic growth and employment and reducing poverty.

Applications for working capital loans for micro business loans and People's Business Credit have credit requirements for debtors that must be completed first. In the assessment of working capital credit for MSMEs, both general and KUR, the following requirements are met:

1) Requirements for Micro Business Credit (KUM)

a. Minimum 2 years of business in a location with the same line of business.

b. Minimum age 21 years or already married. Maximum age 60 years when the credit is paid off.

c. Attach proof of identity in the form of an identity card or ID card with a family KK card and a marriage certificate for those who are married.

d. Special credit Rp. 50,000,000.00 and above required NPWP (Taxpayer Identification Number)

e. Business certificate from the village or kelurahan, market office or local authority where the person concerned has a business.

f. Business license.

g. Have never obtained a credit facility or have obtained a credit facility with current collectibility or not in a non-performing credit condition

2) Requirements for People's Business Credit (KUR)

a. Applicants' legal documents, such as ID cards and family cards.

b. Business legality documents, for example NPWP (Taxpayer Identification Number), SIUP (Trade Business License), SKDU (Certificate of Business Domicile).

c. Photocopy of checking or savings account for the last 6 months.

Both Micro Business Credit (KUM) and People's Business Credit (KUR) the main criteria for prospective debtors at Bank Mandiri Malang are the age of the prospective debtor at least 21 years or already married and the minimum business age of the prospective debtor is 2 years. After the debtor completes the requirements above, then micro credit sales proceed to the next stage, namely the initial survey. The initial survey conducted by basic interviews includes the debtor's file and the purpose of the debtor to apply for credit, we ask about his business. After that, micro credit sales deepen the prospective debtor by looking for information around the prospective debtor's environment. If after the initial survey conducted by MKS and MKS deem the prospective debtor worthy, the file will be given to the micro-credit analyst. Micro credit analysts will conduct bichecking and field assessments with credit managers and micro business clusters. If the value of the application is above Rp. 50,000,000.00.

BI checking is a system under the auspices of the OJK Financial Services Authority that contains information about a person's banking history and can affect credit ratings. In BI checking there are collectability points as described below:

1) Col 1

Col 1 is a current condition that has never been late in paying. If it is in column 1 then it is called smooth.

2) $\operatorname{Col} 2$

Col 2 is a condition for late payment of credit from 1 month (30 days) to 3 months (90 days). If it is in column 2 , it is called in special attention (DPK).

3) $\mathrm{Col} 3$ 
$\mathrm{Col} 3$ is a condition for late credit payments of more than 90 days to 120 days. If it is in column 3 then it is called substandard $(\mathrm{KL})$.

4) $\mathrm{Col} 4$

Col 4 is a condition for late payment of credit above 120 days to 180 days. If it is in column 4 then it is called doubtful.

5) Col 5

Col 5 is the late payment of credit by more than 120 days to 210 days and above. If it is in col 5 then it is called not smooth (TL).

Collectability points can be used as a reference in credit scoring. From BI checking itself, it can be seen how the character of the debtor is honest and responsible. If the debtor applying for credit is in column 2, then the debtor must fulfill his obligations first. After doing BI checking micro credit, the analyst proceeds to the next stage, namely field assessment. This field assessment is carried out with the credit manager. If the application is above Rp. 50,000,000.00 Micro Business Cluster participates in credit assessment and provides credit decisions. In the field assessment, the credit manager visits the prospective debtor and makes an assessment by interviewing and seeing the real condition of the prospective debtor. Meanwhile, micro-credit analysts conduct analysis and review in order to be more convincing to the Court of the debtor. Darmawi (2012: 53) explains the steps in qualitative and quantitative risk assessment, including 1) steps in a qualitative risk assessment: collecting information regarding the financial responsibility records of prospective borrowers, determining the purpose of the borrower in borrowing funds, identify the business risk of the borrower in borrowing funds, estimate the level of commitment of the borrower to repay the loan. 2) Steps in quantitative risk assessment: analyzing historical financial data, projecting the results of financial analysis in the future to determine the ability of borrowers to repay their loans in a timely manner.

In credit assessment, at each stage of the assessment, Bank Mandiri uses 5C as the basis for conducting the assessment. Credit assessment uses the $5 \mathrm{C}$ principle to assess the credit application of prospective debtors. This is explained as follows

\section{1) Character}

Character is an assessment of prospective debtors including personality, environment, way of life and history. According to Mr. Nur and Mrs. Lisa, character is the main thing in the assessment, according to Mr. Yusron, capacity is more important than character. In terms of character, according to Mr. and Mrs. Lisa, Bank Mandiri expects debtors to have an honest and responsible character, while Mr. Yusron added another important character, namely bankable. According to Ismail (2011:112) Banks want to know that prospective debtors have a good character, are honest and have a commitment to repaying loans that will be received from the bank. In assessing the character of Bank Mandiri Wahid Hasyim in achieving its goals,

\section{2) Capacity}

Capacity affects the debtor's ability to pay for his credit. According to Mr. Yusron, capacity is very important compared to character. The capability referred to includes the business ability and the ability of the debtor. The main ability is the ability of its business from business capacity, turnover to dependents on the debtor. the response of the debtor in question is whether the income from his business can meet the needs of the debtor and the debtor's obligations. In terms of business capabilities, Bank Mandiri does not see the financial statements in assessing MSMES credit at Bank Mandiri, in contrast to the theories and research that have been previously stated that use financial reports as credit assessments. Saraswati (2012) stated that financial statements can be used as the basis for approval of credit. In fact, Bank Mandiri does not look at its financial statements in terms of capacity, only looks at how much turnover is, how much profit is taken, how much can be produced per day, how the debtor pays off his obligations such as paying for electricity and water, to how is the relationship between the debtor and its suppliers. This was asked by the Micro Business Manager to the debtor and the micro credit analyst conducted a survey of the debtor's suppliers to have more confidence in the debtor's ability. Assessment in terms of capacity aims to determine the ability to pay debtors, thereby reducing credit risk. to How is the relationship between the debtor and its suppliers. This was asked by the Micro Business Manager to the debtor and the micro credit analyst conducted a survey of the debtor's suppliers to have more confidence in the debtor's ability. Assessment in terms of capacity aims to determine the ability to pay debtors, thereby reducing credit risk. to How is the relationship between the debtor and its suppliers. This was asked by the Micro Business Manager to the debtor and the micro credit analyst conducted a survey of the debtor's suppliers to have more confidence in the debtor's ability. Assessment in terms of capacity aims to determine the ability to pay debtors, thereby reducing credit risk.

\section{3) Capital}

Capital is wealth or capital owned by prospective debtors in their business activities. An assessment can be made based on information regarding the source and structure of capital, the quality of capital management, the effectiveness of the use of capital placement, the quality of profit creation and the quality of profit utilization (Artthesa and Handyman, 2006:172). Bank Mandiri assesses that Capital can be seen from the stock in the debtor's business and can be seen from the conditions in the 
debtor's business, it can be seen from the business equipment. Similar to the assessment in terms of capacity, capital should also be seen from the financial statements, but Bank Mandiri does not require financial reports in conducting credit assessments. Bank Mandiri only looks at the existing stock in the debtor's business.

\section{4) Collateral}

Collateral is an asset belonging to the debtor given to Bank Mandiri as credit collateral. According to Bank Mandiri, the guarantee itself is a tool to protect if the debtor breaks his promise, it will blow it. The validity of the guarantee must also be examined so that if a problem occurs, the guarantee deposited will be used as soon as possible (Kasmir, 2012: 96). According to Mr. Yusron, before assessing Capital, micro credit sales will ask for guarantees first. Bank Mandiri performs a guarantee assessment in accordance with what is guaranteed. If the collateral is a motor vehicle, a physical inspection of the vehicle will be carried out, if the collateral is land, a survey will be carried out in the area of the reflected land. land valuation in the form of the width of the road environment of the land to be guaranteed, ownership in the land certificate to be guaranteed, the land area is recalculated to ensure the land area is the same as that in the land certificate, and how much land value will be pledged as collateral. Ismail (2011:113) in detail the consideration of collateral, among others, known as MAST:

\section{a. Marketability}

Collateral received by the bank must be collateral that is easily traded at an attractive price and increases from time to time so that if there is a problem with the repayment of the credit, the bank will easily sell the collateral.

\section{b. Ascertainability of value}

The collateral received has a more definite price standard, because I asked for an item that is still easy to obtain, so there is no need to ask for help from an appraisal agency in estimating the price of the item I asked.

\section{c. Stability of value}

Collateral submitted by the bank has a stable price so that when the collateral is sold, the proceeds from the sale can cover the debtor's obligations.

\section{d. Transferability}

Collateral submitted by the bank has been transferred physically and legally. Every young person to be able to buy collateral, does not need to do complicated permits.

Guarantees at Bank Mandiri are also divided into two, namely collateral to be bound and collateral not to be bound. Bound guarantees are guarantees that have a value of more than Rp. 25,000,000.00 and are bound by a notary. Meanwhile, unrestricted guarantees are guarantees that have a value below Rp. 25,000,000,00 and do not need to be bound by a notary.

\section{5) Conditions of economy}

The condition of economy referred to here is an assessment of macroeconomic conditions. However, there is a difference between Mr. Yusron and Mr. Nur. Mr. Yusron in the assessment of working capital credit for micro-business conditions Of Economic is rare and valuable, because macroeconomic conditions, especially inflation, do not have much effect on MSMES businesses. However, according to Mr. Nur, macroeconomic conditions are not only influenced by inflation, but also become a calculation in the assessment of the condition of economy. According to Kasmir (2012: 96) in assessing their children's credit, the economic and political conditions now and in the future are also assessed according to their respective sectors and the business prospects of the sector they run.

\subsubsection{Nominal Determination System for MSMES Working Capital Loans at Bank Mandiri Malang}

The system for determining the nominal working capital credit of MSMEs at Bank Mandiri is based on capacity and collateral. This is in accordance with the research conducted by Katili et al. (2014) regarding the determination of the working capital credit limit for MSMEs at Bank Mandiri's Dotulolong Lasut Manado branch, which also came to see the ability to pay or pay off debtor's credit obligations in setting the amount of the credit limit or ceiling.

\section{1) Capacity}

Capacity, the ability of prospective debtors to pay is the main influence in determining the nominal credit. An analysis process is needed in determining the nominal credit so as not to reduce the risk in granting credit. Credit managers negotiate lending to debtors and micro credit analysts analyze to determine the right loan nominal. The analysis of determining the nominal credit uses a system filled with micro credit analysts covering the income and business profits of the debtor. 
After being analyzed, the analyst will get the limit of ability to pay or the debt service ratio of the debtor's DSR. Bank Mandiri DSR provisions are a maximum of 35\%, not more than 35\%. For more details, the method for calculating the nominal credit is as follows:

For example, A applies for a loan of Rp. 25,000,000.00 with flat installments of Rp. 1,225,000 per month in 2 years. A turnover of $50 \mathrm{~B}$ rupiah per month with a profit of $10 \%$, then.

Income

$$
=\text { Rp. } 50,000,000.00 \times 10 \%
$$$$
=\text { Rp. 5,000,000.00 }
$$

Ability to pay

$$
\begin{aligned}
& =\text { Rp. } 5,000,000,00 \times 35 \% \\
& =\text { Rp. } 1,750,000.00
\end{aligned}
$$

So, A is considered eligible to get a credit with the ability to pay a maximum of $35 \%$ DSR of IDR $1,750,000$.

However, the above needs to be analyzed again whether with an income of Rp. 5,000,000.00 and the ability to pay Rp. $1,750.000,00$, so the cost of living is Rp. 3,250,000. negotiations to increase the nominal credit to A. However, if it is deemed insufficient, the analyst can lower the DSR to below $35 \%$ and then recalculate it with income to find a decent credit nominal for A.

\section{2) Collateral}

Bank Mandiri itself has provisions in terms of guarantees for credit applications. If the selected credit application has a minimum collateral value of credit, the opposite if the selected KUR credit application the guarantee value can be below the credit nominal. Other provisions, if there is a criteria for the year if the vehicle is a vehicle and if the land is pledged as collateral, there must be the name of the prospective debtor, the name of a parent, or the name of a sibling. This guarantee is also one of the factors in determining the nominal credit. If the value of the guarantee is greater than that proposed and the debtor has the ability, it is possible that Bank Mandiri will offer a higher credit nominal.

\subsubsection{Constraints and solutions for assessing and granting credit to MSMEs at Bank Mandiri Malang}

In credit assessment, it is possible that there will be obstacles in credit assessment. Considering that credit is an asset to the nation, there must be a solution to the problems in credit assessment and they must be resolved immediately.

\section{1) Obstacles from prospective debtors}

One of the obstacles in conducting the assessment is the constraint of the prospective debtor itself. In the problem of credit assessment, when a prospective debtor is one example, the debtor is embarrassed if there will be an assessment of the land that will be used as collateral. If the prospective debtor is embarrassed when an assessment will be carried out by Bank Mandiri, this will be an obstacle for analysts in conducting the assessment and it will be difficult to decide whether the land is feasible or not as collateral for the debtor's credit application. The solution to the problems faced by prospective debtors is to provide education to prospective debtors.

\section{2) Obstacles in assessing character}

To know a person's character is indeed very difficult. This is also felt in the analysis of credit assessments. Character assessment becomes an obstacle because the analysis and the debtor do not meet regularly. The solution to the problem in assessing character is that the analysis is required to be sharp and adhere to the 5Cs so that they can conduct interviews well.

\section{3) Constraints from MKS and MKA}

Constraints caused by MKS and MK themselves. These obstacles occur because MKS and MKA do not have control over the business of prospective debtors. The business of prospective debtors is the initial provision for an MKS and MKA in conducting an assessment. If MKS and MKA do not understand and have information about the debtor's business, then the credit assessment will not be optimal. The solution is if you are looking for information about the prospective debtor's business frequently with similar businesses, Googling and reading books.

\section{4) Obstacles due to calamity or disaster}

The last obstacle is a constraint that cannot be taken into account, namely the debtor is affected by a natural disaster or disaster. This constraint has been taken into account when assessing credit. Disasters or natural disasters can create nonperforming loans. To find out if there is a disaster or natural disaster, monitoring is needed for maintenance and the solution is restructuring. Restructuring is rescheduling or re-analysis of credit payments. 


\section{CONCLUSIONS AND SUGGESTIONS}

\subsection{Conclusion}

\section{1) Assessment of MSMES Working Capital Loans at Bank Mandiri Malang}

a. The criteria for MSMEs that are considered eligible for working capital credit at Bank Mandiri.

Meet the requirements for working capital credit, both general and KUR as determined by Bank Mandiri. The general requirement is that the debtor's business is at least 2 years in a location with the same line of business and the debtor's age is at least 20 years old or married. Maximum age of 60 years when the credit is paid off.

b. Measures for assessing MSMES working capital loans at Bank Mandiri.

The steps for assessing working capital loans carried out by Bank Mandiri are as follows: conducting an initial survey conducted by micro credit sales including interviewing applications that have been filled in by the debtor and files or documents that have been collected by the debtor as well as conducting an assessment of the surrounding environment, micro credit analysts conducting BI checking after MKS deems the debtor applying for credit is deemed worthy then the file will be submitted to the micro credit analyst. BI checking displays all the history of prospective debtors including the status of debtor payments, requests for credits that have been obtained, interest on guarantees that have been submitted. Bank Mandiri expects the debtor to be in column 1 status. If it is in column 1 status and above, then Bank Mandiri asks the debtor to fulfill the debtor's obligations first. Conduct field assessments carried out by micro credit analysts, Micro Business Managers, and micro business clusters if the application is above Rp. 50,000,000.00 secretly. The Micro Business Manager or credit manager will visit the customer by conducting interviews and seeing the real condition of the debtor. Meanwhile, microcredit mobile analysts in the neighborhood around the debtor are looking for information about the debtor, the minimum number of informants needed by the Court is 3 informants.

In each of the assessment steps all based on $5 \mathrm{C}$. The $5 \mathrm{Cs}$ referred to are as follows: a) character, the debtor character expected by Bank Mandiri to be honest, responsible and bankable. Character can affect the fulfillment of debtor obligations. b) Capacity, capacity assessed by Bank Mandiri includes the business ability of the prospective debtor, the dependents of the prospective debtor, to the obligations of the prospective debtor in the form of electricity and water. The debtor's business ability can also be assessed from its production, determining the price of production, turnover, profit taking, so that the relationship between debtors and suppliers is established. c) Capital, Bank Mandiri expects that if you apply for a working capital loan at Bank Mandiri, the debtor must already have initial capital and allocate it according to his business needs. Bank Mandiri does not want the application for working capital credit to be used as initial business capital. To assess credit in terms of capital, it can be assessed from the debtor's business stock. d) collateral, in the assessment of collateral, Bank Mandiri will assess the physical guarantee and the authenticity of the letter to be guaranteed. Bank Mandiri does not accept collateral if it is in the name of another person, it is still permissible if the guarantee is in the name of a parent or sibling. e) condition of economy, a micro assessment of economic conditions includes inflation and trends. This assessment is also important for micro-enterprises to reduce credit risk. Assessment using 5C between character, capacity, capital, collateral and condition of economy are interrelated and if assessed correctly will reduce the risk in lending. To assess credit in terms of capital, it can be assessed from the debtor's business stock. d) collateral, in the assessment of collateral, Bank Mandiri will assess the physical guarantee and the authenticity of the letter to be guaranteed. Bank Mandiri does not accept collateral if it is in the name of another person, it is still permissible if the guarantee is in the name of a parent or sibling. e) condition of economy, a micro assessment of economic conditions includes inflation and trends. This assessment is also important for micro-enterprises to reduce credit risk. Assessment using 5C between character, capacity, capital, collateral and condition of economy are interrelated and if assessed correctly will reduce the risk in lending. To assess credit in terms of capital, it can be assessed from the debtor's business stock. d) collateral, in the assessment of collateral, Bank Mandiri will assess the physical guarantee and the authenticity of the letter to be guaranteed. Bank Mandiri does not accept collateral if it is in the name of another person, it is still permissible if the guarantee is in the name of a parent or sibling. e) condition of economy, a micro assessment of economic conditions includes inflation and trends. This assessment is also important for micro-enterprises to reduce credit risk. Assessment using 5C between character, capacity, capital, collateral and condition of economy are interrelated and if assessed correctly will reduce the risk in lending. in the collateral assessment, Bank Mandiri will assess the physical guarantee and the authenticity of the letter to be guaranteed. Bank Mandiri does not accept collateral if it is in the name of another person, it is still permissible if the guarantee is in the name of a parent or sibling. e) condition of economy, a micro assessment of economic conditions includes inflation and trends. This assessment is also important for micro-enterprises to reduce credit risk. Assessment using 5C between character, capacity, capital, collateral and condition of economy are interrelated and if assessed correctly will reduce the risk in lending. in the collateral assessment, Bank Mandiri will assess the physical guarantee and the authenticity of the letter to be guaranteed. Bank Mandiri does not accept collateral if it is in the name of another person, it is still permissible if the guarantee is in the name of a parent or sibling. e) condition of economy, a micro assessment 
of economic conditions includes inflation and trends. This assessment is also important for micro-enterprises to reduce credit risk. Assessment using 5C between character, capacity, capital, collateral and condition of economy are interrelated and if assessed correctly will reduce the risk in lending. This assessment is also important for micro-enterprises to reduce credit risk. Assessment using 5C between character, capacity, capital, collateral and condition of economy are interrelated and if assessed correctly will reduce the risk in lending. This assessment is also important for micro-enterprises to reduce credit risk. Assessment using 5C between character, capacity, capital, collateral and condition of economy are interrelated and if assessed correctly will reduce the risk in lending.

2) The system for determining the nominal working capital credit of MSMEs at Bank Mandiri Malang

a. Capacity, capacity can be obtained from the debtor's income and then Bank Mandiri analyzes it in terms of income which is then multiplied by the maximum DSR limit of 35\%. If the results of the maximum DSR limit are obtained, then the income is reduced and the rest is able to meet the challenges and obligations of the debtor, the ability to pay is at the $35 \%$ DSR limit.

b. Collateral, in terms of collateral can affect the nominal credit. At Bank Mandiri, there are provisions for applying for guarantees. This is distinguished according to the type of credit, namely if the selected credit application has a minimum nominal credit guarantee value, the opposite if the selected KUR credit application the guarantee value can be below the credit nominal.

3) Constraints and solutions for assessing and granting credit to MSMEs at Bank Mandiri Malang

a. Obstacles from prospective debtors, for example when debtors are embarrassed if an assessment will be carried out, the solution is to provide education to prospective debtors.

b. Obstacles in assessing character, obstacles in exploring character because they do not meet daily, the solution is to be sharp and stick to the $5 \mathrm{Cs}$ so that they can conduct interviews well.

c. Constraints from MKS and MKA do not control the business of prospective debtors. The solution is to find information about the prospective debtor's business by sharing with similar businesses, Googling and reading books.

d. Obstacles that cannot be taken into account are natural disasters or disasters. To find out the problem, monitoring is needed to play in and the difference is restructuring.

\subsection{Suggestions}

Based on the results of the study, the suggestions that researchers can give are as follows:

1) For PT Bank Mandiri Persero Tbk

a. When the researcher asked micro credit sales, micro credit analysts and micro business managers to rank the most important of the 5C principles for assessing credit and view the important points in credit scoring from the 5C principles, the answers between micro credit sales, micro credit analysts, and micro business managers different. credit sales considers that the condition of economy has no effect on MSMEs, because according to MKS the important point in credit assessment of the condition of economics is inflation. However, micro credit analysts and micro business managers do not have the same understanding as micro credit sales because the point in assessing the condition of the economy is not only inflation. issues and trends are also influential points in credit assessment from the point of view of the condition of economy.

While microcredit sales, microcredit analysts, and micro business managers ranked the most important in the 5C's for credit scoring, they also differed. Micro credit sales view that the most important thing is ability, while micro credit analysts and Micro Business Managers are compact in choosing the most important character in assessing credit.

The difference in views should be paid more attention to considering that credit is a ripple asset for banks. It is better if the views of credit scorers in one environment are uniform.

Judging from the different views on the 5C principles in credit assessment, Bank Mandiri needs to be given an understanding of the $5 \mathrm{Cs}$ in order to understand the Selaras credit assessment.

b. From the debtor's statement that monitoring is carried out once a year. there should be a monthly monitoring system that is very useful to ensure that working capital loans given to debtors are used for their intended purpose. The existence of regular monitoring is also expected so that Bank Mandiri does not lose track of the debtor, if the debtor tries to act fraudulently. In addition, monitoring is also useful to avoid bad loans which will actually harm Bank Mandiri itself. 
c. Provide special programs to support debtors' businesses both in terms of marketing and managerial. This is done so that the installments will be more guaranteed and there is a possibility that the debtor will reapply for top up credit. Bank Mandiri will also benefit, because other MSMEs that have never applied for credit at Bank Mandiri will be interested in applying for credit at Bank Mandiri.

2) For the next researcher

Considering that this research still has various shortcomings, it is hoped that further researchers can develop research on the assessment of MSMES working capital loans in state-owned banks. There are many things about credit assessment at Bank Mandiri, especially credit for MSMEs that can be discussed. because credit assessment for MSMEs is very interesting to discuss and explore further further researchers can also compare the use of 5C principles in credit assessment among stateowned banks. It is hoped that further research can determine differences in credit assessment among state-owned banks and look for these differences. It is hoped that future researchers will get unique findings in credit assessment using the 5C principle used by 2 different state-owned banks to be discussed.

\section{REFERENCES}

Afandi, P. 2010. Analysis of 5C implementation of BPR Banks in Determining Eligibility of Providing Credit to Customers Case Study At PD point BPR Salatiga bank and PT BPR Kridaharta Salatiga. Scientific Journal Among Makati. Vol 3 No 5:55-69.

Arthesa, A and Handiman, E. 2016. Banks and Non-Bank Financial Institutions. Jakarta: Index.

Darmawi, H. 2012. Banking Management. Jakarta: Earth Literacy.

Firdaus R and Ariyanti, M. 2011 Commercial Bank Credit Management: Theory of Policy Problems and Its Applications Complete with Credit Analysis. Bandung: Alphabeta.

Ishmael. 2011. Banking Management Theory Towards Application. Jakarta: Kencana.

Kasmir. 2012. Banks and Other Financial Institutions. Jakarta: PT Rajagrafindo Persada.

Katili, MI, Tommy, P. and Untu V. 2014. Credit Eligibility and Determination of Working Capital Credit Ceiling for Prospective MSMES Debtors at PT Bank Mandiri (Persero) Tbk Dotulolong Lasut Manado Branch. Emba's Journal. Volume 2 Number 1: 470-479.

Law of the Republic of Indonesia Number 20 of 2008 concerning Micro, Small and Medium Enterprises.

Moleong, L J. 2012. Qualitative Research Methods. Bandung: PT. Offset Rosdakarya Youth.

Muljono, P., T. 2001. Credit Management for Commercial Banks. Yogyakarta: BPFE-Yogyakarta.

Munawir. 2015. Analysis of Financial Statements. Fifteenth Printing. Liberty. Yogyakarta

Pato, S. 2013. Analysis of Micro Credit Provisions at Bank Syariah Mandiri Manado Branch. Emba's Journal. Volume 1 Number 4: 875-885.

Saraswati, AR 2012. The Role of Financial Statement Analysis, 5C Assessment of Prospective Debtors and Credit Supervision on the Effectiveness of Credit Provisions at PD BPR Bank Pasar Temanggung Regency. Nominal Journal. Volume 1 No.1.

Sugiyono. 2018. Combined Research Methods (Mixed Methods). Bandung: CV Alfabeta.

Suhardjono. 2003. Small and Medium Business Credit Management. Yogyakarta: Publishing and Printing Unit (UPP) AMP YKPN. 